Clients appearing before the board tre to eubmit prepared reasons stating why they should be considered on the two counts. The Immigration Officer reads this and proceeds to question the client about any possibleciminal recond, whether the client's parents are alive, and issues concerning the person's economicactivities. Clientsare restrained from stating their reasons for seeking refugee status, since this is not a full hearing session. The Officer closes the interview upon his determination whether the client's case is inadequate and should move to the full hearing.

We have several concerns with the wholeoperation. What specifically forms

"Our concern here is that
unless the essential reality
of a particular client's
circumstances is taken
into consideration,
assessment on the basis of
some generalised and
preconceioed guidelines
will unavoidably lead to
their unfair treatment."

the basis for consideration on humanitarian and compassionate groundo? If the clients are forbidden from stating their motivation for seelding efuge in Canada, what else could form he besis for determining their eligibility or consideration on humanitarian and compassionate grounds? If the assesement places much premium on financial and pb security, what will be the fate of those who had to whit for 20 ong for a work permit? if the famlly is iscigned enomous importance, would lot it be dieadvantageoys to those who ave not been able to bring their family re? Similarly if the degree of integration to the Canadian social envingnment is rer-etressed, those who have pot been ithis country long enough will eufier.
We are not trying to trivialize or downplay the importance of these sodal factors. Where the consideration for compassionate and humanitarian grounds is unclear, officials in control might emphasize certain requirements as against others, or they might use their own discretion leading to the rejection of many applicants. Our concern here is that unless the escential reality of a particular client's circumstances is taken into consideration, assessment on the basis of some generalised and preconceived guidelines will unavoidably lead to their unfair treatment. It appears the whole process dwells too muchondrawing implication from verylittieinformation misidudgment and miscalculation. If a client's motive for seeking refuge is not the fundamental basis for establishing his or her eligibility. for consideration on compassionate grounds, then why should not the interview be called off?

On the basts of the above concerns raised here we would like to recommend that drastic changes be made in these humanitarian and compassionate reviews to enable it to befit its tille. Firet, it is onily appropriate that adequate measures be tiken to ensure that two waycommunications between clients and officials be eatabliahed to allow for comprehension of the proceedings. This neceseltates the provialon of interpretere in required circumotances. Secondly, it to ridiculous that such a process should be rushed through. Sufficient time should be allocated to each case to feciltinte a determined rearch for ingredients and potentialities which will quallify thectient for consideration. Lasty, we deen it absolutely necesany that the factors forming the bads of these humanitarian reviews be outlined, explained and justified to enable daimants to know the criteria for judging. In the abeence of all the above, the humanitarian and compassionate review has become symptomatic of an ect put on to glorify and celebrate a supposedly humanistic refugee determination process, while, in reality, clients are faced with a fact-paced and incomprehencible exercise, merely carried out bo satiofy the Redernl Court's ruling $\square$

\section{AN OPEN LETTER TO THE IMMIGRATION MINISTER}

\section{Dear Ms. McDougall:}

Several members of the Inter-Church Committee for Refugees were at York Univerdity on Sunday May 27th 1990 to hear you raise important questions in your speech at the Refugee Policy Conference dinner. The questions you raised are timely and deserve an equally serlous response.

\section{Southeast Ala - Comprohendive} Pian of Action

Wehavesupported the governmen In its efforts to arrive at a negotiated solution to the refugee situation in Southeast Asin. We share you reservations about the adequacy of the determination procedures. The Canadian policy debate has put great emphads on a good hearing for the initial determination. This view should be shared in Asia to ensure informed independent decision making at the first stage.

\section{Internationd Solutions}

Protecting and providing solutions for the world's refugees are, as you say, beyond the means of any one country. However, it is only fair to point out that If the resources in your cocth procen for the backlog in Canada were made avallable to the UNHCR, the ennald crisis would be colved in the short term. Thus, whilemost countriescenfind come formula to be satiefied with theirshare of the contributions, the fact remins that all countries need to increase thetr core contributions to the UNHCR aignificantily. If the UNHCR does not have the resources to satiafactorly maintain refugees where they are, more refugees will be forced to move on, seeking their own solutions.

\section{Rolative Enort In Polltical and Humanitarian Areas}

The cost of political and humanitarian programs differ in kind and extent. Poitical hitiatives go on all the time. It is more a question of what 
isoue to focus on. This is a time to focus on refugee producing situations. Effort should go into resolving those regional conflicts and responding to those international human rights violators which are the source of the major fraction of the world's refugees. Refugee arrivals in Canada provide a crude measure of world problem areas. The Refugee Board's own statistics for the first three months of 1990, rankcountries of refugee origin: 1. Sri Lanka, 2. Somalia, 3. China, 4. Iran, 5. El Salvador and 6. Lebanon. These six countries account for about $75 \%$ of the first quarter claims in Canada.

Canada's commitment to an international solution in South East Asia is commendable. Canada's noticeably low key delegation to the first international meeting of the follow-up. committee of the International Conference on Central American Refugees, CIREFCA, June 27, 28, 1990, was, however, inappropriate. Canada has a special responsibility to respond to, and to be seen to respond to, problems in our own world region.

Political efforts are needed to head off new refugee producing situations. Kenya is a case in point. Kenyn has the potential to support human rights and thus the trend towards its becoming a major human rights violator and hence major refugee producer might yet be averted.

Efforts towards an international response to the general problems of internally displaced persons, such as our proposed special rapporteur from the UNCommission on Human Rights, could also do much to avert new refugee flows.

\section{The Balance of Refugee Resources Spent in Canada and Overseas}

Comparing money spent on refugees in Canada with money spenton those outside is not simply a question of resources. Somerefugee related activities are international legal obligations. The protection of personsin Canadaisa treaty obligation Canada has accepted. The ICCR has already made suggestions about how both refugee determination and the backlog process could be made more just and more cost effective. They nonetheless remain a Canadian responsibility.

Other refugee related activities, such as the assistance and resettlement of refugees, are a moral obligation. The interests of the refugees for protection and some solution must always be uppermost. However, that said, theissue becomes what can be done most costeffectively by Canada in Canada and what can bedone most cost effectively on an international collective basis. The resettlement area is one where the collective international mechanismunder the UNHCR is the best approach. UNHCR already seeks solutions for refugees as part of itsmandate. It already determines persons as refugees in need of the resettlement solution. It already notes whether there is a rationale such as a link for asking Canada to resettle. The question arises why Canadian officials,

$$
\begin{aligned}
& \text { "Some refugee related } \\
& \text { activities are international } \\
& \text { legal obligations. The } \\
& \text { protection of persons in } \\
& \text { Canada is a treaty } \\
& \text { obligation Canada has } \\
& \text { accepted." }
\end{aligned}
$$

at great cost, should second guess this proceser.

Present family procedures take significant resources from other immigration programs. Family reunion could be vastly more humane with great savings if family members of persons in Canada were simply allowed to travel here. Presently, they are systematically delayed in coming from several countries because they get neither visitor's visas nor minister's permits. Of course, these family members might stay if their relative in Canada is a refugee. If they didstay, the cost of proceseing here would be marginal on the procesing already underway. Some $80 \%$ of asylum seekers are presently allowed to stay in Canada and virtually $100 \%$ of their families will come to Canada anyway. It is hurtful to the family and costly to Canada to spend money delaying the inevitable.

These factors come together. Large increases in asylum seekers in Canada are the direct consequence of the present balance of initiatives and programs. The number of refugees in the world has continued to increase. Monies provided by governments including Canada for UNHCR programs have not kept pace. This pressures refugees to find their own solutions in western countries. The complexity of family programs and the freezeongovernmentresettlement places since 1985 also pressures refugees to abandon this "safety valve", and to seek their own solutions. The suspension of travel loans, the delays and the talk of review will have a dampening effect on private sponsorship. This too will encourage those who can to seek their own solutions. Those most hurt will be the most vulnerable refugees caught in limbo overseas such as the high risk person, the single parent with a family, the large family.

\section{Balancing Efforts towards the World's Disadvantaged and Canada}

Everyone in Canada is of particular concern to Canadian churches irrespective of their status as Canadians or tourists or anything else. The issue becomes the relative effort Canadian churches put into empowering different groups or classes of persons in Canada and the help we give our church partners abroad. This is a question as real for churches as it is for government. The answer must be found in political balancing. We have not found chunch refugee work has detracted from church work among Canadian groups who hurt or from our overseas programa.

We have found the task of reflecting on your thoughtful questions helpful for our work. We hope our thoughts will asoist you in yours

Yours sincerely, Helga Kutz-Harder Acting Chair, Inter-Church Committee for Refugees 